\title{
Media Massa, Pemerintah dan Pemilik Modal
}

\author{
Eko Harry Susanto \\ FIKOM, Universitas Tarumanagara
}

\begin{abstract}
Abstrak
Demokratisasi dalam komunikasi, merupakan titik tolak media massa dalam mendorong tercapainya masyarakat informasi yang sejahtera. Namun persoalannya, tidak mudah membangun demokrasi yang ideal. Sebab sejumlah kalangan di tubuh pemerintahan masih mengedepankan kekuasaan dalam menyikapi pesan - pesan yang disampaikan oleh media. Di sisi lain, masih ada pemilik modal yang menafsirkan bahwa demokrasi identik dengan kebebasan bertindak yang merugikan bisnis yang dijalankan. Namun hambatan demokrasi yang dikaitkan dengan transparansi pemberitaan bisa saja muncul dari masyarakat yang lebih menyukai ketertutupan akibat jargon masa lalu tentang harmoni dan keselarasan.
\end{abstract}

Kata Kunci : Media massa, kekuasaan pemerintah dan pemilik modal

\begin{abstract}
Democratization of communication, is the starting point of mass media in promoting the achievement of a prosperous information society. But the problem, is not easy to build a democratic ideal. Because a number of people within the government still puts power in response to the message - the message conveyed by the media. On the other hand, there are still investors who interpret that identic democracy with freedom of action which is detrimental to the business is run. But democracy barriers associated with reporting transparency could have emerged from people who prefer introversion past due jargon about harmony and alignment.
\end{abstract}

Keywords: mass media, the government and the power of capital owners

\section{Pendahuluan}

Memasuki era reformasi politik, kemerdekaan berekspresi dan demokratisasi komunikasi, selalu mewarnai blantika retorika elite kekuasaan negara, elite politik, pemilik modal dan pemegang otoritas sosial - budaya di masyarakat. Tetapi demokrasi seringkali ditafsirkan kebebasan dalam konteks integralistik untuk kepentingan kelompok dan tidak menghiraukan keberadaan entitas lain yang ada dalam masyarakat. Padahal, sesungguhnya demokrasi mengandung keberadaban dan keteraturan dalam kehidupan bermasyarakat yang memiliki tujuan sangat mulia dalam menjalankan pemerintahan.
Demokratisasi dalam kehidupan berbangsa dan bernegara menuntut kebebasan pers dalam pemberitaan. Lepas dari tekanan pihak yang berkuasa secara sosial-budaya, politik maupun ekonomi. Dalam pandangan Urofsky (2001:2) tentang pemerintahan negara - negara maju yang ideal dan dapat menyejahterakan rakyatnya, pengertian demokrasi adalah " sebuah sistem yang terus tumbuh dan berkembang untuk menjalankan pemerintahan yang berpihak kepada kepentingan publik sebagai pihak yang harus dilayani lebih baik". Artinya demokrasi dalam pemerintahan mengikuti tuntutan jaman namun tetap berpijak kepada pelayanan 
kepada publik yang baik.

Secara umum, untuk menjalankan pemerintahan demokratis yang adil dan makmur, terdapat 11 prinsip untuk memahami dan mempraktekkan demokrasi secara nyata dalam pemerintahan, yaitu : (1) pemerintahan yang berdasarkan pada konstitusi, (2) pemilihan umum yang dilaksanakan secara demokratis, (3) keberadaan pemerintahan lokal yang kuat didukung oleh potensi setempat yang memadai dan dapat dipakai sebagai fondasi pembiayaan, (4) pembuatan undang undang yang berpihak kepada rakyat sebagai bentuk pertanggungjawaban kepada rakyat yang memilih (5) sistem peradilan yang independen dan bebas dari tekanan pihak manapun.

Selain itu aspek lain yang diperlukan dalam menjalankan pemerintahan adalah adalah (6) kekuasaan lembaga kepresidenan sebagai abdi yang bekerja keras dan sepenuh hati untuk kepentingan publik dan bukan menjadi majikan bagi rakyat, (7) peran media yang bebas, independen dan memiliki kemandirian (8) peran kelompok- kelompok kepentingan yang membantu warga dalam kehidupan sosial, ekonomi dan politik, (9) hak masyarakat untuk tahu terhadap berbagai masalah kenegaraan termasuk kinerja pemerintahan, (10) melindungi hak - hak minoritas, (11) terbuka upaya kontrol sipil terhadap peran militer

Semua aspek pendukung demokrasi memiliki peran dan fungsi yang bermanfaat bagi jalannya pemerintahan yang ideal. Secara spesifik dalam konteks peran media yang bebas dan independen, Anokwa, Lin dan Salwen, (2005: 5), menekankan perlunya peran pers yang independendalammendukung demokrasi kehidupan bernegara. Kebebasan pers sejalan dengan kebebasan individual, yang mencakup pula bebas dari intervensi pihak luar maupun dari kekuasaan negara". Sehaluan dengan itu, Blake dan Haroldsen (2009:79) menegaskan, "dalam masyarakat modern, media massa merupakan lembaga sosialisasi pesan pesan baik formal maupun informal yang penting dalam bermasyarakat". Untuk itu, media harus mengorganisasikan pesan yang bermanfaat dan mudah dipahami oleh khalayak

Dengan kata lain, media massa memegang peran penting dalam mendifusikan jalannya pemerintahan yang demokratis kepada rakyat. Menurut McQuail (2005:58), “media beroperasi di ruang publik sesuai kepentingan pengguna, kegiatan utamanya adalah memproduksi, mendistribusikan konten simbolik, dan partisipasi bersifat professional, terarah serta bebas nilai kepentingan"

Dalam hal ini, yang diperlukan adalah media yang tidak dipengaruhi oleh berbagai kekuatan sosial, ekonomi maupun politik dan lebih mengedepankan transparansi informasi kepada khalayak. Pertanyaannya, sejauhmana media massa di Indonesia bisa bersikap independen, lepas dari pengaruh elite dalam pemerintahan, politisi maupun para pemilik pers.

Sebab, kebebasan pers di negara maju sekalipun, tetap menghadapi problem. Departemen Kehakiman AS bersikeras, bahwa penyitaan rekaman telpon wartawan Associated Press (AP) yang dilakukan dalam penyelidikan kebocoran data intelijen hanyalah untuk melindungi warga AS. Masalah ini menjadi polemik yg mempertentangkan kebebasan pers dan kebebasan memperoleh informasi dengan keamanan nasional. (Kompas, 16 Mei 2013). Sesungguhnya Amerika 
Serikat meskipun memiliki peraturan tentang kebebasan informasi publik yang dituangkan dalam Freedom of Information Act, tetapi ada batasan - batasan tertentu dalam menangani masalah nasional (Susanto, 2007).

\section{Legalitas Kemerdekaan Pers}

Secara historis, perbedaan persepsi dan kepentingan masyarakat dan media, tidak bisa lepas dari perjalanan pers di Indonesia. Selama pemerintahan Orde Baru, ada kecenderungan menggunakan paradigma Media Pembangunan yang menempatkan media dalam bingkai “bebas dan bertanggungjawab". Menurut Denis McQuail (2005) pendekatan teori media pembangunan meliputi (1) media seyogyanya menerima dan melaksanakan tugas pembangunan positif sejalan dengan kebijaksanaan yang ditetapkan secara nasional. (2) Kebebasan media dibatasi sesuai dengan prioritas ekonomi dan pembangunan masyarakat, (3). Media perlu memprioritaskan isi pada kebudayaan dan bahasa nasional, (4). Media hendaknya memprioritaskan berita dan informasinya pada negara sedang berkembang lainnya, yang erat kaitannya secara geografis, kebudayan atau politik, (5). Para wartawan dan karyawan media lainnya, memiliki tanggungjawab serta kebebasan dalam tugas mengumpulkan informasi dan penyebarluasannya.

Selain itu, demi kepentingan tujuan pembangunan, negara memiliki hak untuk campur tangan, atau membatasi, pengoperasian media, sarana penyensoran, subsidi, dan pengendalian langsung terhadap media. Pola media pembangunan yang menjadikan pers sebagai instrumen politik pemerintah yang berkuasa, lazim diberlakukan di negara - negara sedang berkembang yang menerapkan sensor serta pengendalian pemberitaan secara ketat. Pers yang bebas akan mengancam kekuasaan pemerintah karena cenderung mengkritisi berbagai kebijakan pemerintah yang tidak berpihak kepada rakyat. (Jayaweera dan Amunugama, 1987).

Dalam koridor pers pembangunan yang memberikan kebebasan semu terhadap jurnalis, maka sesungguhnya semua informasi yang didifusikan oleh media massa, telah melalui proses pengawasan yang berlapis, sehingga berita yang munculpun sesuai dengan kehendak pemegang kekuasaan. Implikasinya, berita yang mengungkap tentang kegagalan penguasa dalam meberikan pelayanan publik yang lebih baik tidak akan muncul. Sebaliknya berbagai entitas di masyarakat yang tidak sehaluan dengan politik pemerintah, akan terus dieksplorasi dari sisi yang membahayakan negara. Dalam belenggu sensor yang ketat, masyarakat yang merasa tidak puas kepada negara, sulit untuk menyuarakan pendapatnya di media massa.

Berpijak kepada gambaran tersebut, sebelum reformasi politik di Indonesia, kehidupan media massa lebih condong masuk dalam karakteristik media pembangunan. Namun sejalan dengan semangat reformasi kenegaraan pada tahun 1998, maka kebebasan pers diformulasikan melalui UU No.40/1999 tentang Pers dan UU No.32/2004 tentang Penyiaran yang menjamin kebebasan media dengan segala konsekuensinya.

Selain itu dalam koridor transparansi informasi yang mendukung kebebasan komunikasi, maka Undang - Undang No. 11 tentang Informasi dan Transaksi Elektronik dan UU No. 14 tahun 2008 tentang Keterbukaan Informasi Publik dapat dijadikan sebagai pedoman dalam menjalankan kebebasan pers. 
Mengingat eksistensi berbagai peraturan sudah mengarah untuk menempatkan media dalam posisi yang independen, demokratis dan transparan, maka pemerintah dengan segala otoritas yang dimiliki, harus mau memposisikan media sebagai institusi bebas, yang tidak bisa dipakai sebagai instrument politik dalam menjalankan kekuasaan. Memang pemerintah dan media massa, mempunyai hubungan yang signifikan karena keduanya memiliki kekuatan. Namun yang menjadi persoalan adalah, relasi antara media massa dan pemerintah tidak selalu berjalan baik, karena dipengaruhi oleh berbagai kepentingan.

Dalam perspektif pers bebas, McQuail, menetapkan sejumlah ciri - ciri yang melekat yang mencakup (1) Publikasi seyogianya bebas dari penyensoran pendahuluan oleh pihak ketiga, (3) Tindakan penerbitan dan pendistribusian media sebaiknya terbuka bagi setiap orang atau kelompok, tanpa memerlukan ijin atau lisensi yang dikeluarkan oleh penguasa (3) Kecaman terhadap pemerintah, pejabat atau partai politik (yang berbeda dari kecaman terhadap orang-orang secara pribadi, atau pengkhianatan dan gangguan keamanan), seyogyanya tidak dapat dipidanakan, bahkan setelah terjadinya peristiwa itu, (4) Seyogyanya tidak ada kewajiban mempublikasikan segala hal di media massa melalui kekuatan politik maupun kekuasaan modal.

Karakter lain pers bebas adalah (5) publikasi kesalahan dilindungi sama halnya dengan publikasi terhadap kebenaran dalam hal yang berkaitan dengan opini atau keyakinan, (6). Selayaknya tidak ada batasan hukum yang diberlakukan terhadap upaya pengumpulan informasi untuk kepentingan publikasi.
Di samping itu, seyogyanya pemberitaan media massa tidak ada batasan hukum yang diberlakukan dalam impor, ekspor, atau pengiriman dan penerimaan pesan, di seluruh pelosok negeri. Sedangkan faktor krusial lain sebagai karakter pers bebas adalah berkaitan erat dengan profesionalisme praktisi media, yaitu wartawan selayaknya mampu menuntut otonomi profesional yang sangat tinggi di dalam organisasi mereka.

Jika merujuk kepada kebebasan berekspresi dan kemerdekaan menyampaikan pendapat, maka dinamika media massa di Indonesia pasca reformasi politik berjalan seiring dengan dengan teori pers bebas. Walaupun ada sejumlah perbedaan dalam aplikasi pemberitaan maupun penyiaran.

\section{Menurunnya Peringkat Kebebasan Pers}

Dalam Seminar yang digelar School for Broadcast Media pada tanggal 11 September 2006, sejumlah praktisi media massa menilai bahwa intervensi terhadap pemberitaan oleh pengusaha maupun penguasa (pemerintah) masih terus terjadi hingga saat ini. Di pihak lain Presiden Susilo Bambang Yudhoyono dalam acara buka bersama dengan pemimpin redaksi dan wartawan, menegaskan bahwa kebebasan pers dan kebebasan rakyat melalui media massa merupakan keniscayaan dalam transformasi menuju demokrasi. (Kompas, 12 September 2006).

Jelas ada kontradiksi antara kondisi faktual yang dialami oleh media massa dengan pernyataan Presiden SBY. Tentu saja, perbedaan ini tidak bisa dinilai sederhana mengingat persoalan krusial yang dihadapi media adalah menghadapi pemerintah dengan segala sub- ordinat kekuasaannya untuk mengendalikan media massa. 
Berdasarkan catatan Surat Kabar Kompas (21 Juli 2010), peringkat kebebasan pers di Indonesia tahun 2009, menduduki posisi nomor tiga di Asia Tenggara. Peringkat pertama diduduki oleh Papua Nugini dan peringkat kedua ditempati oleh Timor Leste. Indonesia pernah menempati posisi utama dalam kebebasan pers di Asia Tenggara pada tahun 2002. Pada tahun yang sama di tingkat dunia menduduki peringkat 57 . Sedangkan posisi tahun 2009 kebebasan pers tingkat dunia, Indonesia yang sudah berupaya menjalankan UU No.40/1999 dan UU No.32/2002 masih berada pada urutan ke 101 di dunia

Penurunan peringkat kebebasan pers ini, diikuti pula oleh melemahnya indeks demokrasi. Berdasarkan Indeks Demokrasi Global (IDG) yang dikeluarkan Economist Intelligence Unit tahun 2010, Indeks Demokrasi Indonesia berada di peringkat ke-60 dari 167 negara dengan skor 6,53. Peringkat ini masih di bawah China yang berada di urutan ke 36, Afrika Selatan (ke-30), Thailand (ke57), Papua Nugini (ke-59) dan bahkan Timor Leste (ke-42). Rendahnya IDG karena lemahnya variabel demokrasi, pemilihan umum, pluralisme, dan fungsi pemerintahan (Kompas, 12 April 20111). Melemahnya demokrasi merupakan ancaman kebebasan pers yang akan berimplikasi kepada kualitas pemberitaan, akibat fungsi media sebagai agen konstruksi sosial masuk dalam perangkap kekuasaan.

Jika merujuk variabel demokrasi, kebebasan pers masih mengalami berbagai problem internal berkaitan dengan kebijakan institusi media, maupun masalah eksternal berhubungan dengan pemberitaan yang diasumsikan tidak independen dalam bingkai masyarakat majemuk. Tetapi, terkait dengan teori isi media dan realitas sosial, maka harapan tertinggi masyarakaty terhadap kebenaran realitas, tetap saja dilekatkan pada berita dan informasi yang didifusikan oleh media massa konvensional maupun media mainstream.

Karena itu, meskipun bermunculan media alternatif maupun media sosial baru, yang menyampaikan pesan melalui perangkat media transmisi pesan yang didukung teknologi komunikasi (Biagi, 2005: 7), tetapi media massa konvensional, meskipun dalam bayang - bayang ancaman demokrasi, masih menjadi referensi kuat bagi masyarakat dalam mencari informasi yang dipercaya. Mills (1968:32) menandaskan, kita masih belum percaya terhadap informasi, sampai kita membaca atau mendengarkannya dari radio. Sebuah testimoni klise yang masih relevan dengan kondisi sekarang, di mana media massa dianggap sebagai sarana pembenaran terhadap informasi. Benar ini pendapat kuno sebelum marak pertumbuhan media sosial yang didukung oleh teknlogi komunikasi, tetapi dalam dinamika pemberitaan dan penyiaran di Indonesia, media konvensional masih memiliki kekuatan di masyarakat.

Menyangkut kepercayaan publik terhadap media sosial yang semakin meningkat dan bergerak progresif, Presiden SBY juga membuka akun twitter untuk mengikuti trend perkembangan teknologi komunikasi untuk berinteraksi dengan massa. Walaupun pembukaan akun tersebut belum mencerminkan munculnya komunikasi yang interaktif antara pemimpindan rakyat. Berdasarkan jajak pendapat majalah Tempo ( 5 Mei 2013), 73 persen responden tidak percaya bahwa akun twitter mempermudah SBY berkomunikasi dengan publik, 22,3 persen menyatakan mempermudah, sisanya 3,9 persen menjawab tidak tahu. Jadi intinya, pemanfaatan teknologi 
untuk berinteraksi dengan massa secara demokratis tanpa sekat, tetap merujuk kepada tindakan faktual yang dilakukan oleh pemerintah dan tidak sebatas membuka kran informasi dari rakyat. Oleh sebab itu, media massa konvensional harus menjunjung tinggi transparansi dan kebebasan berkomunikasi agar tetap menjadi rujukan masyarakat dalam menyikapi berbagai hal yang terjadi disekelilingnya.

Sesungguhynya upaya menghambat kemerdekaan pers dan kebebasan berekspresi bukan hanya muncul dari elite dalam kekuasaan negara saja, sebab masyarakat yang masih mengunggulkan ketertutupan dalam budaya patronage, akibat jerat model komunikasi di masa lalu dalam bentuk yang vertikal, masih memiliki peran kuat untuk menghambat independensi maupun transparansi media. Walaupun tidak bisa diabaikan, penolakan terhadap kemerdekaan pers lebih menguat karena dukungan kelompok elite di tubuh pemerintah yang merasa terganggu kekuasaannya.

Padahal, dalam berbagai pembahasan tentang pelayanan kepada publik di negara dengan tingkat kesejahteraan yang memadai, Johnson (2003:54), menyatakan, pemerintah yang demokratis, harus memberikan perlindungan yang lebih besar terhadap pesan - pesan politik yang kritis dari media massa. Sebab kritik lewat media massa mendorong terbentuknya praktek kekuasaan yang demokratis dalam memberikan kesejahteraan kepada rakyat. Dengan demikian, bukan secara konfrontatif melawan kritik media massa yang berupaya menyuarakan keterbukaan informasi kepada khalayak.

Tanpa menafikan upaya dari penguasa untuk mengendalikan media massa, tetapi yang juga mengkhawatirkan adalah intervensi terselubung terhadap pemberitaan dan penyiaran media massa yang dilakukan oleh pemilikmodal.Gejala umum tindakan menguasai pemberitaan dengan memanfaatkan kelemahan kepemilikan media dan praktisi media dalam hal finansial, sehingga pemilik modal dapat menitipkan berbagai berita yang dikehendaki oleh para pengusaha.

Dalam konteks aplikatif, para pemilik dana dalam upaya menciptakan relasi dengan kekuasaan, mereka menyampaikan pesan khusus lewat media dalam bentuk iklan ucapan selamat kepada pejabat publik, iklan yang memberi dukungan terhadap kebijakan pemerintah. Tindakan lain, misalnya dengan memanfaatkan sejumlah orang yang memiliki keunggulan sosial maupun politik, diminta bicara di media dengan tujuan menggeser substansi masalah yang merugikan rakyat akibat ulah perusahaan, menjadi persoalan bersama dan tanggungjawab bersama. Tidak jarang, pengusaha yang berhasil karena pola - pola bisnis masa lalu, menggunakan sejumlah opinion leader untuk menyalahkan kondisi saat ini, dengan mengkomparasikan situasi sebelumnya dalam bentuk penyampaian pesan sederhana yang mudah dipahami masyarakat.

Cara lain yang dilakukan pemilik modal tentu sangat beragam, tetapi umumnya berujung kepada menggunakan media untuk kepentingan pribadi ataupun kelompok dan di berbagai media lokal yang tidak didukung oleh fondasi keuangan yang memadai, mereka akan terjebak dalam aneka kontrak halaman, kontrak berita dan berbagai hal yang melemahkan independensi maupun transparansi pemberitaan yang berpihak kepada publik.

Kondisi tersebut, jelas tidak lepas dari pengaruh kehidupan pers di masa 
lalu, dimana elite politik, penguasa pemerintah dan pemilik modal terbiasa dalam lingkaran pemberitaan yang seragam dengan jargon-jargon klise dari para apemegang kekuasaan negara. Pesan-pesan di dalamnya pada umumnya mengeksplorasi pelaksanaan kegiatan pemerintah dalam sisi manajemen informasi pemerintah yang mengunggulkan model komunikasi massa tanpa gejolak, atau serasi dan selaras seimbang. Tentu saja terlepas dari upaya membangun komunikasi yang seragam tersebut dilakuan dengan tindakan otoritatif dan represif, yang berlindung di balik stabilitas keamanan untuk mendukung pembangunan dalam penafsiran yang integralistik.

Oleh sebab itu, pada saat reformasi politik bergulir dan membuka peluang munculnya pers bebas, maka sejumlah entitas yang semula memperoleh perlindungan "manajemen pemberitaan pemerintah" secara istimewa, selanjutnya merasa tidak nyaman, dan berusaha secara terus menerus menyuarakan pula tuduhan bahwa media maassa di Indonesia kebablasan. Bisa saja memang ada sejumlah media yang terlampau bebas dan tidak mengindahkan kode etik jurnalistik yang dipakai sebagai pedoman oleh jurnalis dari berbagai kelompok yang tidak lagi tunggal seperti pada masa sebelum reformasi.

Tetapi bukan berarti transparansi informasi yang disuarakan oleh media identik dengan pemberitaan yang tidak beraturan, kebabalsan dan pemicu konflik vertikal, antara pemerintah dengan rakyat, atau konflik horisontal yang terjadi di antara masyarakat. Bagimanapun juga keterbukaan informasi membawa membawa berbagai perubahan yang signifikan dalam kehidupan bernegara yang demokratis menuju masyarakat informasi yang beradab.

\section{Simpulan}

Media mempunyai posisi strategis dalam mendukung demokratisasi kehidupan berbangsa dan bernegara. Namun untuk membangun karakter media yang transparan dalam pemberitaaan, penyiaran independen dan bebas dari kepentingan politik maupun bisnis, bukan pekerjaan yang mudah. Mengingat hal ini diperlukan proses yang sangat panjang untuk menyesuaikan antara etika demokrasi yang substantif dengan sejumlah kalangan maupun masyarakat yang masih terperangkap dalam pelembagaan ketertutupan dan harmonisasi pemberitaan sebagai dampak dari penggunaan media sebagai instrumen pemerintah dan politik yang berkuasa.

Dalam konteks kepentingan bisnis yang dijalankan media, memang benar bahwa media boleh menjalankan bisnis untuk menghidupi organisasinya agar mampu menjadi sumber informasi yang kredibel, tetapi regulasi yang ada, yang sudah memberikan kemerdekaan dan kebebasan berekspresi, namun tetap harus lebih mengedepankan kepentingan untuk memberikan informasi yang bermanfaat dan faktual kepada khalayak.

Namun persolannya, kalaupun media sudah berupaya profesional dalam mengedepankan idealisme dan bisnis, tetapi secara empirik tidak mudah untuk menjalankan pers bebas untuk menuju masyarakat informasi. Sebab masyarakat pada umumnya masih terbelenggu dalam budaya komunikasi paternalistik, yang memposisikan komunitas maupun kelompok dominan atau yang mempunyai karakteristik spesifik, melalui kekuasaanya, bisa mengontrol informasi.

Alhasil pemberitaan media yang sudah berusaha semaksimal mungkin berpijak kepada kaidah jurnalistik 
yang beretika, dan didukung oleh profesionalisme wartawan, tetap saja sewaktu - waktu akan menuai persoalan dengan masyarakat ataupun elite dalam kekuasaan negara, yang terganggu dengan transparansi informasi yang disebarkjan oleh media.

Hakikatnya, ketika kemerdekaan pers sudah menjadi rujukan dalammengelola media tetapi masyarakat semakin kritis dalam menyikapi kebebasan berekspresi yang ditranformasikan media, tetapi persoalannya, sejumlah entitas di pemerintahan, politisi, pemilik modal dan masyarakat pada umumnya, sering berlindung dibalik demokrasi integralistik, yang ditafsirkan secara sepihak, ketika mengkritisi pemberitaan media dan bukan mustaahil berujung kepada serangan fisik terhadap sejumlah praktisi media massa.

\section{Daftar Pustaka}

Anokwa, Kwadwo, Carolyn A. Lin and Michael B.Salwen.2003. International Communication : Concepts and Cases, Wadsworth Publishing

Biagi, Shieley .2005.Media/ Impact : An Introduction to Mass Media. Seventh Edition, United States : Thomson Wadsworth.

Jayaweera, Neville and Sarath Amunugama. ed.. 1987. Rethinking Development Communication : The Asia Mass Communication. Singapore : Kefford Press Pte Ltd.

Johnson, John W. 2003. “ Peran Media Bebas" dalam Demokrasi, Jakarta : USISINFO State Goverment.

Kompas.2006. Kebebasan Pers, 12 September 2006

Kompas.2010." Peringkat Kebebasan Pers di Indonesia, tanggal 21 Juli 2010 -.2011. “Indonesia Kalah Oleh Timor Leste", tanggal 12 April 2011
-2013. Kebebasan Pers: Pemerintah Dahulukan Keamanan Nasional, tanggal 16 Mei 2013

McQuail, Denis McQuail. 2005. McQuail's Mass Communication Theory, fifth Edition, London : Sage Publications.

Melvin I. Urofsky .2001. " Naskah Pertama, Pendahuluan : Prinsip Prinsip Dasar Demokrasi" dalam Demokrasi, USIS : Jakarta.

Mills, C. Wright. 1968. The World Outside And The Picture In Our Head, dalam Alan Costy (ed) Mass Media And Mass Man, New York, Rinehort And Winston

Susanto, Eko Harry. 2007.Keterbukaan Informasi dan FOIA, Jakarta: Media Indonesia, 17 Oktober

Tempo, Majalah.2013. Kicau Yudhoyono Bukan Solusi, tanggal 5 Mei 2013

Undang - Undang Republik Indonesia Nomor 40 Tahun 1999 tentang Pers, dalam " Hukum Jurnalistik", Jakarta : Seri Pustaka Yustisia

Undang - Undang Republik Indonesia Nomor . 32 Tahun 2002, Tentang Penyiaran, Jakarta : Penerbit Utama.

Undang - Undang Republik Indonesia Nomor 11 Tahun 2008, Tentang Informasi dan Transaksi Elektronik, Jakarta : Penerbit Departemen Komunikasi dan Informatika Republik Indonesia

Undang - Undang Republik Indonesia Nomor 14 Tahun 2008 Tentang Keterbukaan Informasi Publik. Jakarta : Penerbit Departemen Komunikasi dan Informatika Republik Indonesia. 